УДК 377.1:004.9

Глущенко Володимир Володимирович

аспірант

Інститут інформаційних технологій і засобів навчання НАПН України, Київ, Україна reveikf@mail.ru

\title{
ПРОЕКТУВАННЯ СИСТЕМИ ПІДТРИМКИ ДИСТАНЦИЙНОГО НАВЧАННЯ ПРОФЕСІЙНО-ТЕХНІЧНОГО НАВЧАЛЬНОГО ЗАКЛАДУ
}

\begin{abstract}
Анотація. У статті розглядаються система підтримки дистанційного навчання (СПДН) професійно-технічних навчальних закладів (ПТНЗ) на базі системи Moodle. Розглядаються особливості проектування і використання СПДН у ПТНЗ; проектування структури СПДН ПТНЗ; основних етапів впровадження СПДН у освітній процес ПТНЗ на базі Moodle. Розробляється прототип СПДН ПТНЗ і на його основі розгортається СПДН Державного навчального закладу «Черкаський професійний ліцей».
\end{abstract}

Ключові слова: інформаційно-комунікаційні технології; дистанційне навчання; система підтримки дистанційного навчання; електронний навчальний курс; Moodle.

\section{1. ВСТУП}

Освіта важлива для будь-якої людини, особливо в умовах інформатизації суспільства, коли попит на освічених робітників постійно зростає і вимагає від них навчання протягом життя. Через різні обставини у більшості людей немає можливості отримувати освіту ні очно, ні заочно. Але вихід $є$ - дистанційне навчання (ДН). Цю форму освіти прийнято називати системою освіти двадцять першого століття.

Дистанційна форма навчання (ДФН) - форма організації навчального процесу в закладах освіти (ВН3, ЗПО, ПТНЗ, ЗНЗ), яка забезпечує реалізацію дистанційного навчання і передбачає можливість отримання випускниками документів державного зразка про відповідний освітній або освітньо-кваліфікаційний рівень [1].

Основними умовами розвитку дистанційної форми навчання $\epsilon$ [2]:

- позитивний вплив на розв'язання комплексу соціально-економічних проблем засобами дистанційно-віртуальної освіти;

- ліквідація відставання периферійних районів від їх центрів шляхом отримання вільного доступу до освіти й залучення до великих обсягів інформаційних ресурсів і культурних досягнень людської цивілізації;

- об'єднання інформаційного, інтелектуального, творчого та науковопедагогічного потенціалу всього світового співтовариства в інтересах учнів;

- організація інклюзивного i неперервного навчання, навчання дорослого населення, здійснення підвищення кваліфікації без відриву від виробництва;

- підняття рівня освіти до високотехнологічного рівня розвинених держав, інтеграція у європейський освітній простір.

Використання ДФН надає можливість швидко оновлювати і підтримувати інформаційні освітні ресурси. Завдяки цьому можна значно збільшувати навчальну аудиторію. Вона надає можливість рівного доступу до якісної освіти різних категорій учнів (зокрема з обмеженими можливостями), максимально наблизити свої сервіси до спеціальних потреб тих, хто здобуває освіту. Важливою перевагою ДФН є додаткова свобода учня, що виникає під час вибору і реалізації своєї індивідуальної навчальної траєкторії [3]. 
Упровадження ДФН у ПТНЗ потрібне для розширення цільової аудиторії учнів, для скорочення витрат учнів на навчання, отримання ПТНЗ додаткових прибутків від надання освітніх послуг, а також для того, щоб «іти в ногу із часом», який вимагає використання інноваційних методів навчання і мобільних способів здобування знань.

Постановка проблеми. Необхідність розв'язання проблеми інформатизації ПТНЗ зумовлена підвищенням ролі ІКТ у суспільстві, а також їх безпосереднім використанням у системі професійно-технічної освіти (ПТО). Наразі, на сучасному етапі розвитку ПТО існують суперечності, аналогічні тим, що мають місце й у вищій школі [4], зокрема: між потребами в інформатизації ПТО України і рівнем кваліфікації педагогічного персоналу ПТНЗ у галузі застосування ІКТ у навчальному процесі; швидкістю змін апаратного і програмного забезпечення IКТ і темпами вдосконалення професійних компетентностей викладачів ПТНЗ; вимогами щодо неперервності підвищення професійної кваліфікації викладачів професійно-технічної школи й обмеженістю форм, засобів і тривалості навчальної діяльності в системі післядипломної освіти і підвищення кваліфікації; нагальними практичними завданнями з упровадження IКТ у навчальний процес ПТНЗ, зокрема технологій дистанційного навчання (ТДН), у підготовці майбутніх фахівців комп'ютерних спеціальностей, i недостатнім науково-методичним супроводом упровадження цих технологій i неготовністю значної частини викладачів ПТНЗ України до здійснення відповідної інноваційної діяльності.

Тому актуальною суспільно значущою проблемою нині є проблема проектування систем підтримки дистаниійного навчання (СПДН) для ПТНЗ, які є основою для розгортання освітнього середовища дистанційного навчання у иџи закладах, їх упровадження в реальний освітній прочес, а також підготовка викладачів $і$ учнів ПТНЗ до широкого використання технологій дистанційного навчання у своїй діяльності.

СПДН для навчальних закладів, як правило, створюються на базі систем управління навчанням (LMS - Learning Management System). Якщо розглянути основні галузі промисловості, які використовують LMS, то можна побачити, що майже п’ята частина належить освіті (рис. 1).

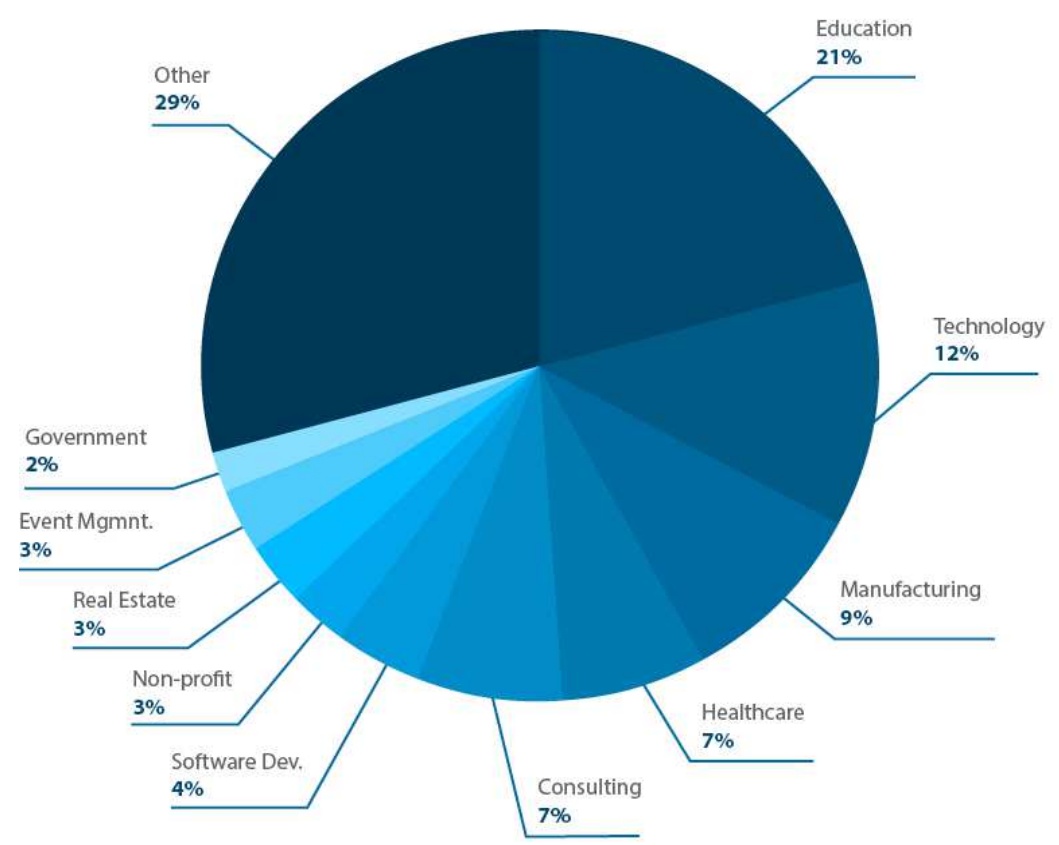

Рис. 1. Основні галузі промисловості, які використовують LMS 
3 рис. 2 видно, що однією $з$ найпоширеніших LMS, які використовуються для управління навчанням, $є$ вільно поширювана система Moodle, що підтримує мережу сертифікованих партнерів і має понад 71 мільйон користувачів [16].

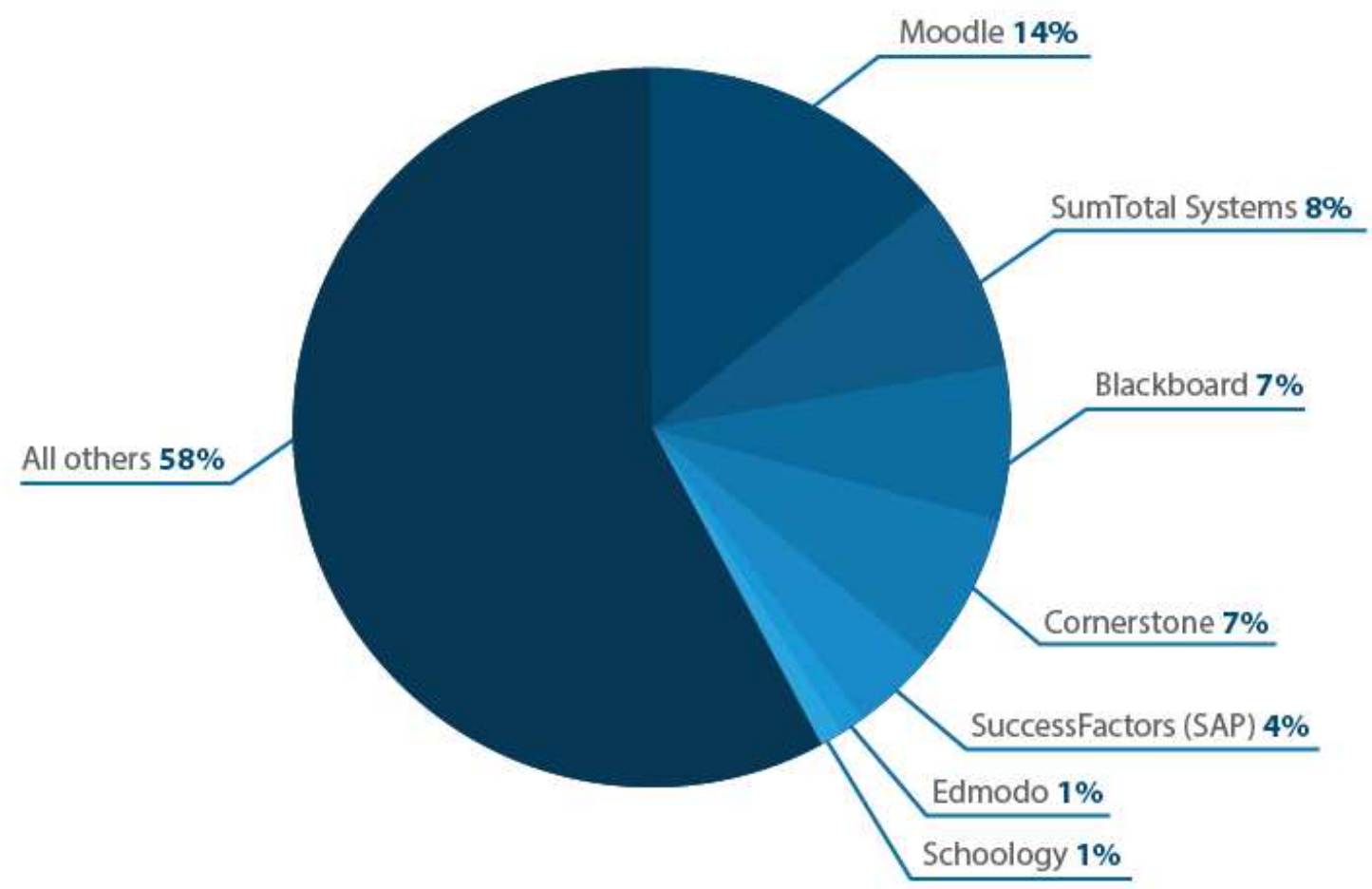

Рис. 2. Програмне забезпечення для організації дистаниійного навчання

Саме тому метою дослідження є проектування системи підтримки дистанційного навчання професійно-технічних навчальних закладів на базі системи Moodle.

Завданням статті є розгляд особливостей проектування і використання СПДН у ПТНЗ; проектування структури СПДН ПТНЗ; розгляд основних етапів упровадження СПДН в освітній процес ПТНЗ на базі Moodle, розробка прототипу СПДН ПТНЗ і на його основі розгортання СПДН Державного навчального закладу «Черкаський професійний ліцей».

Аналіз останніх досліджень і публікацій. Теоретичні i практичні питання використання технологій дистанційного навчання і проблеми впровадження цієї форми навчання в освітніх закладах різного рівня висвітлюються в роботах X. Becker, R. Berger, А. А. Андреєва, О. В. Аніщенко, В. Ю. Бикова, В. П. Зінченка, В. П. Колмогорова, В. М. Кухаренка, А. Ф. Манако, Г. С. Молодих, Н. В. Морзе, О. В. Рибалко, О. М. Самойленка, Н. Г. Сиротенка, С. О. Сисоєвої, П. В. Стефаненка, Е. Г. Скибицького, Г. М. Татурчука, Ю. В. Триуса, А. В. Хуторського, Б. І. Шуневича, та ін. Переважно ці роботи присвячені проблемам використання ТДН у вищій школі і післядипломній освіті.

Аналіз наукових публікацій свідчить про те, що науковці починають все більше уваги приділяти технологічним аспектам управління освітою. Зокрема, педагогічні аспекти інформатизації освіти й управління нею досліджують Т. І. Давиденко, П. Т. Гурій, Г. В Єльникова, О. М. Сльникова, Л. В. Калініна, М. В. Плескач та ін. Проблеми створення інформаційних систем управління в галузі освіти, у тому числі в системі ПТО, були предметом досліджень таких науковців, як В. Ю. Биков [6], Н. Ю. Величко [6], Л. А. Майборода [9]. 


\section{2. РЕЗУЛЬТАТИ ДОСЛІДЖЕННЯ}

\section{1. Структура СПДН ПТНЗ}

Для забезпечення процесу ДН у ПТНЗ повинно бути створене освітнє середовище дистанційного навчання (ОС ДН), яке $є$ системно організованою сукупністю традиційних i комп'ютерно-орієнтованих засобів навчання, засобів діалогу i передавання даних, протоколів взаємодії, систем мультимедія, ІКТ, інформаційних ресурсів, системного апаратно-програмного йа організаційно-методичного забезпечення, орієнтовану на задоволення освітніх потреб користувачів дистанційного навчання [9]. Таке середовище може створюватися, зокрема, на базі систем управління навчанням, таких як: Moodle [11], Edmodo [12], SkillSoft [13], Schoology [14], Instructure [15], що є одними з найпопулярніших систем такого класу [16].

Важливою складовою ОС ДН ПТНЗ повинна стати система підтримки дистанційного навчання. У нашому дослідженні будемо дотримуватися такого тлумачення поняття системи підтримки дистанційного навчання - це багатофункціональний, модульний, мультимедійний, апаратно-програмний комплекс для підтримки дистанційного навчання учнів (студентів), побудований із застосуванням мережних i web-технологій [4].

До складу СПДН, як одного з найважливіших компонент освітнього середовища ПТНЗ, повинні входити такі підсистеми [4]:

- підсистема управління користувачами;

- підсистема повідомлень;

- підсистема доступу до курсів дистанційного навчання і підтримки мобільного навчання;

- підсистему автоматизованого контролю і тестування;

- підсистема обліку результатів навчальної діяльності учнів;

- підсистема управління курсами дистанційного навчання.

Окрім основних компонентів СПДН ПТНЗ доповнимо ще деякими підсистемами, зокрема:

- підсистемою доступу до хмарних сервісів;

- підсистемою управління науково-дослідною діяльністю викладачів і учнів ПТНЗ.

СПДН має не тільки надавати учням доступ до навчальних матеріалів, але й забезпечувати їх можливістю віддаленого спілкування 3 викладачем, оперативно отримувати коментарі від нього, а також спілкуватися з іншими учнями, які вивчають відповідний курс.

За сприяння Черкаського державного технологічного університету спроектовано $\mathrm{i}$ розгорнуто систему підтримки дистанційного навчання ДНЗ «Черкаський професійний ліцей» на базі системи управління навчальним контентом Moodle 2.3 [17].

Для організації навчання, контролю й оцінювання навчальної діяльності учнів у середовищі СПДН створено загальну структуру організації навчального процесу ПТНЗ за рівнями освіти, напрямами підготовки, спеціальностями, курсами навчання та семестрами (рис. 1).

У цій структурі на першому рівні ієрархії здійснюється розподіл за рівнем освіти:

- загальна середня освіта - підготовка учнів на базі 9-ти класів;

- повна загальна середня освіта - підготовка учнів на базі 11-ти класів.

На другому рівні ієрархї здійснюється розподіл за напрямами підготовки (наприклад, «будівельний», «автотранспортний», «електроенергетичний», «інфраструктурний» та ін.). 


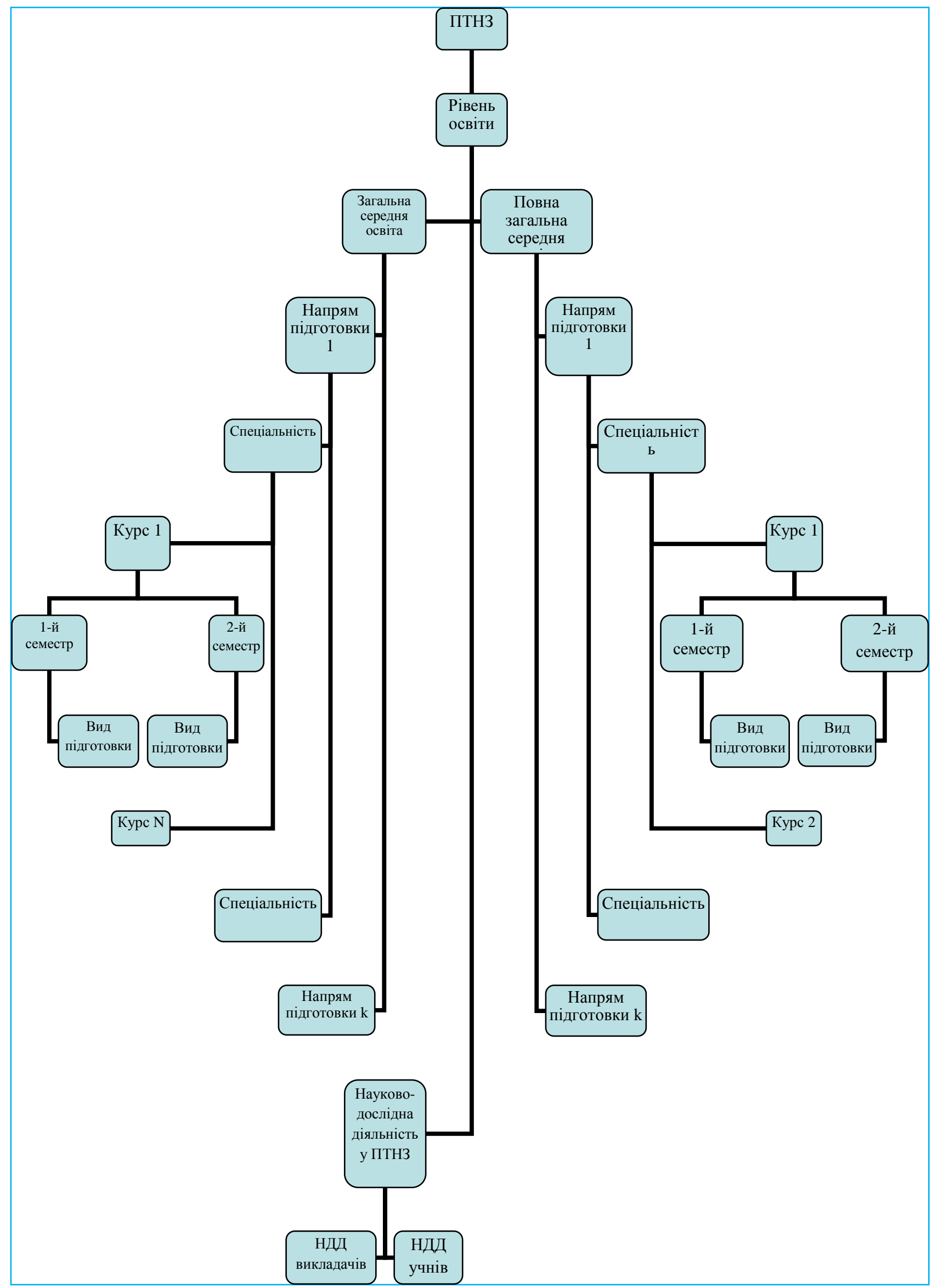

Рис. 3. Структура організачії навчального процесу ПТНЗ 
На третьому piвні ієрархії для кожного напряму здійснюється розподіл за спеціальностями. Для кожної спеціальності здійснюється розподіл по курсах (роках навчання) залежно від рівня освіти, загальна середня освіта - 3 роки, а повна загальна середня освіта - 2 роки. Кожен курс навчання містить у собі дві підкатегорії: 1-ц̌ семестр $i$ 2-й семестр. Кожен семестр поділяється на види підготовки (загальнопрофесійна підготовка, професійно-теоретична підготовка, професійнопрактична підготовка, природничо-математична підготовка, суспільно-гуманітарна підготовка).

Також було створено структуру виду підготовки, загальний вигляд якої представлений на рис. 4. Для кожного виду підготовки визначено відповідні предмети, а за кожним предметом закріплені відповідні групи учнів (рис. 6).

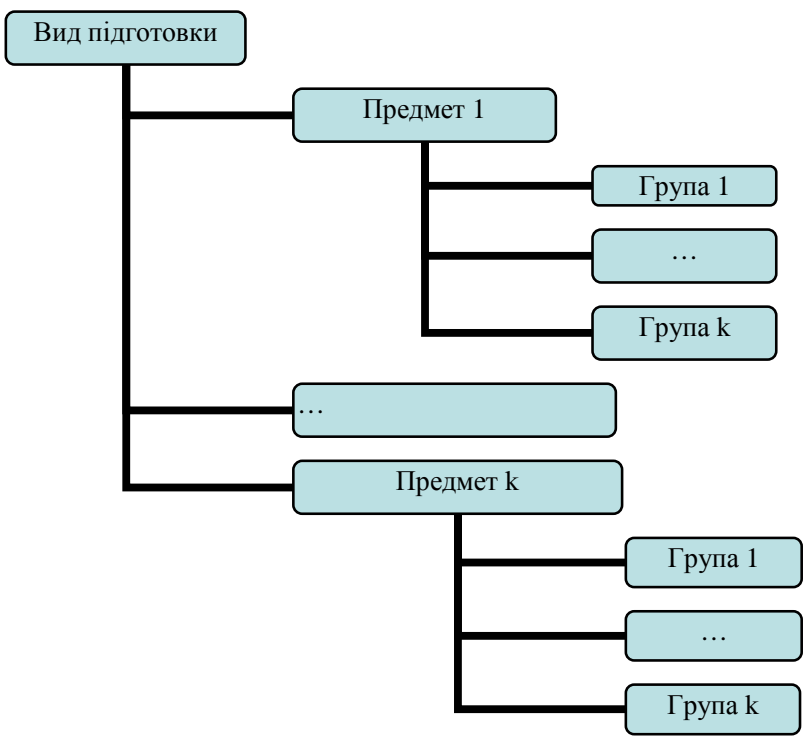

Рис. 4. Структура категорії «Вид підготовки» в організачії навчального процесу ПТНЗ»

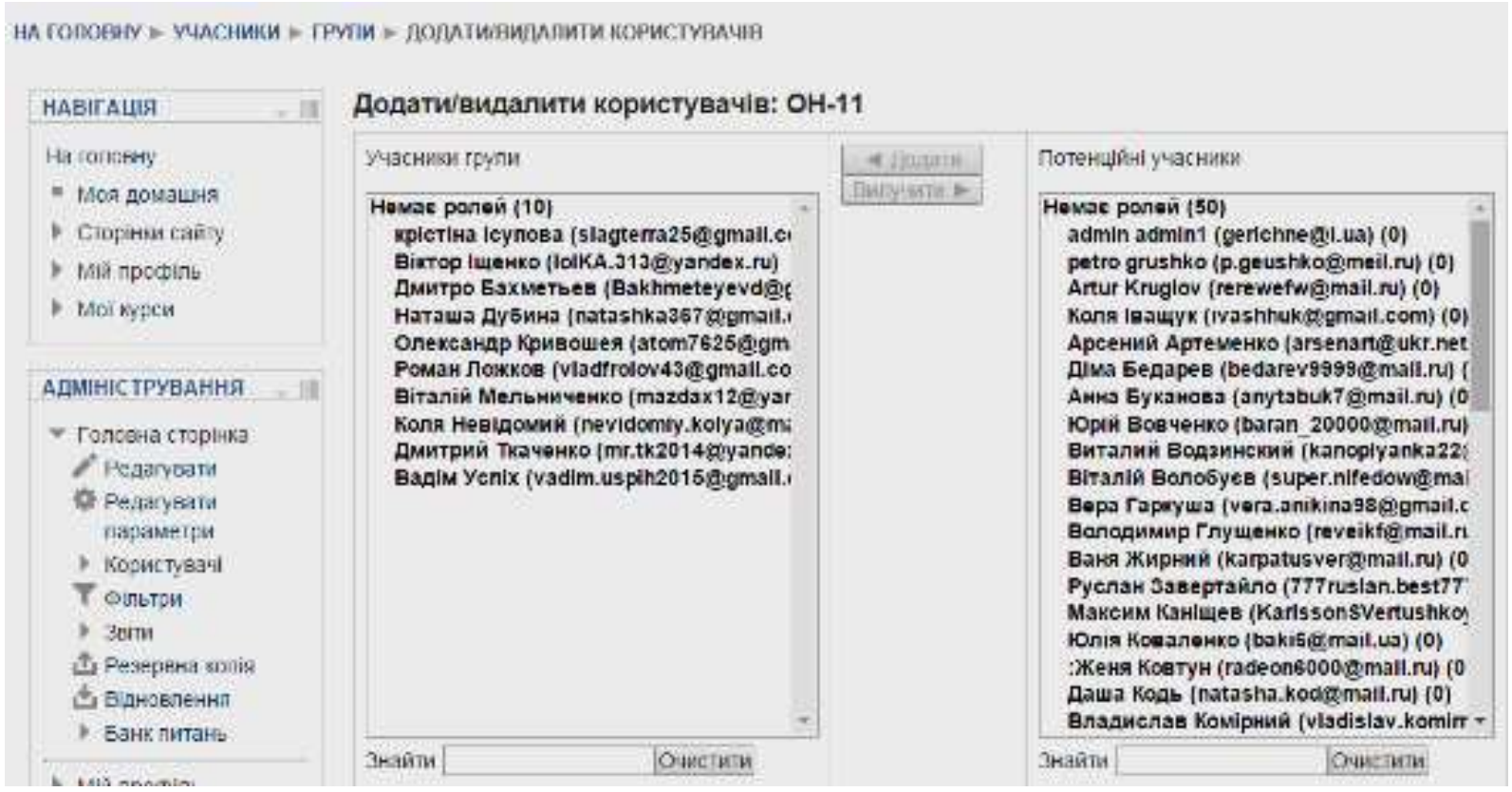

Рис. 5. Вікно перегляду «Списків групи» 
Ця структура організації навчального процесу ПТНЗ реалізована під час створення СПДН ДНЗ «ЧПЛ» на базі Moodle 2.3 [17] і представлена на рис. 6.

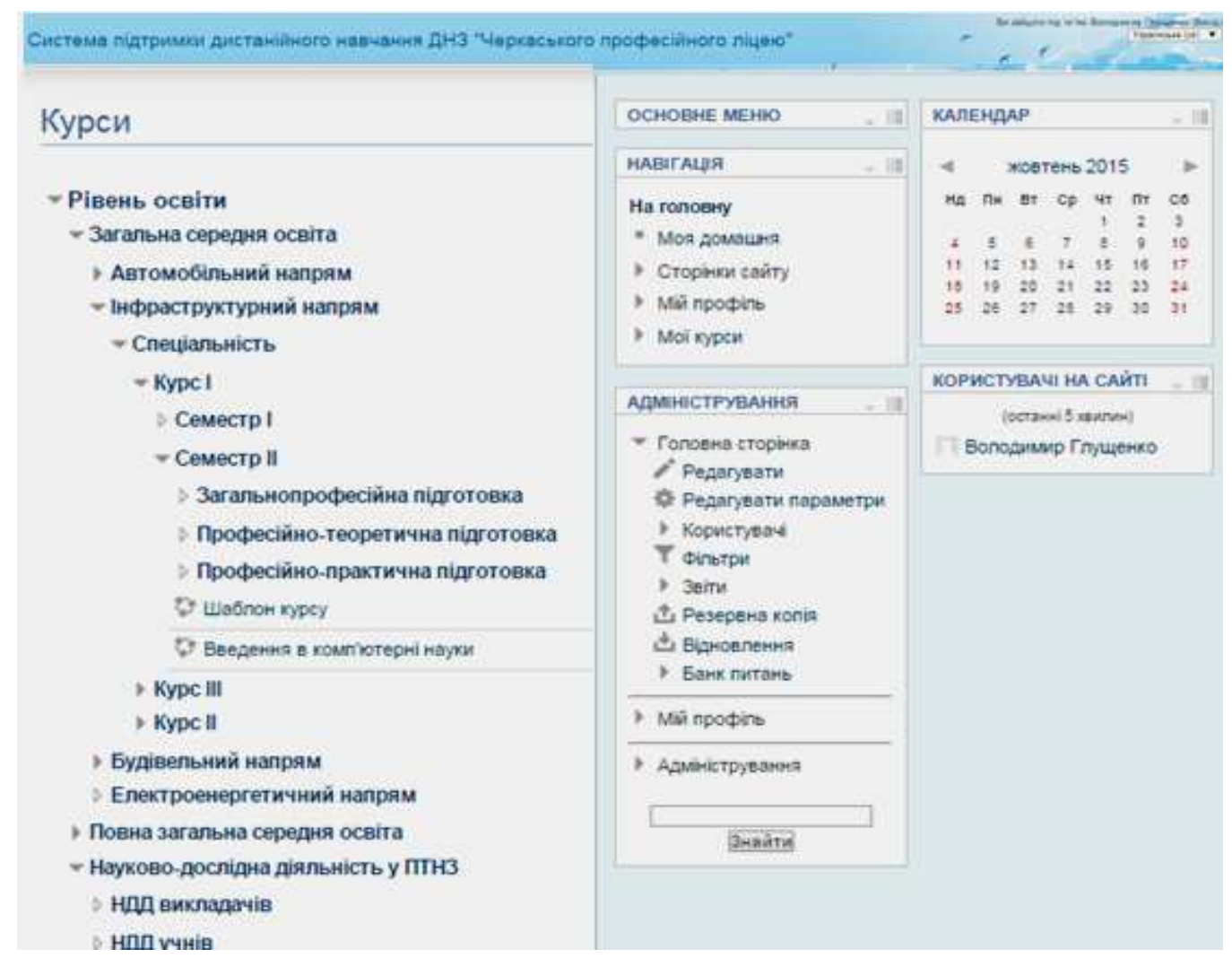

Рис. 6. Головна сторінка СПДН ДНЗ «Черкаський професійний ліией»

Для початку роботи із СПДН ДНЗ «ЧПЛ» потрібно зайти на сайт, де встановлено цю систему [17]. На головній сторінці СПДН відображена загальна структура ПТНЗ, список категорій і підкатегорій. Учень, що зареєструвався в СПДН, має можливість обирати будь-яку категорію.

Наприклад, якщо обрати категорію «Загальна середня освіта» (рис. 7), то у вікні з’явиться відомості про цю категорію, а також відомості про ії підкатегорії.

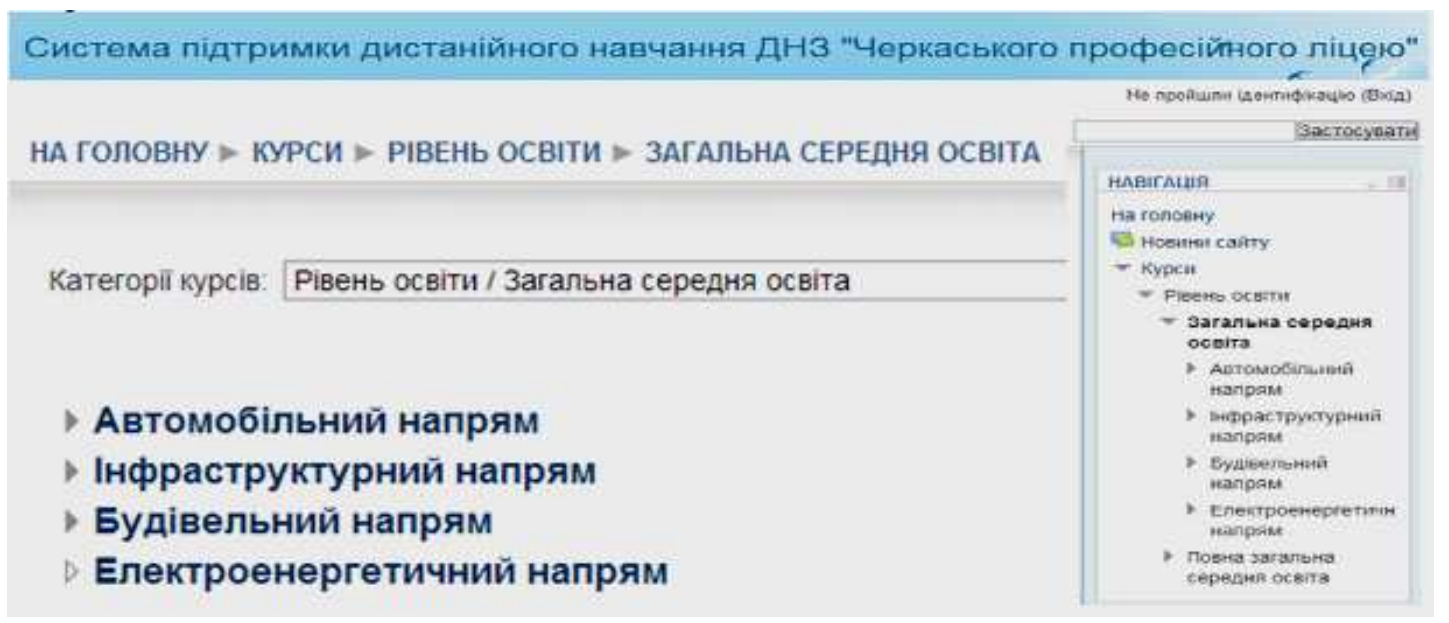

Рис. 7. Результат обрання підкатегорії «Загальна середня освіта» 
Далі користувач повинен обрати один із напрямів підготовки. На рис. 8. зображено результат обрання підкатегорії «Інфраструктурний напрям».

Далі користувачу пропонується обрати спеціальність. Потім користувачу пропонується обрати курс навчання і потрібний навчальний семестр (рис. 9).

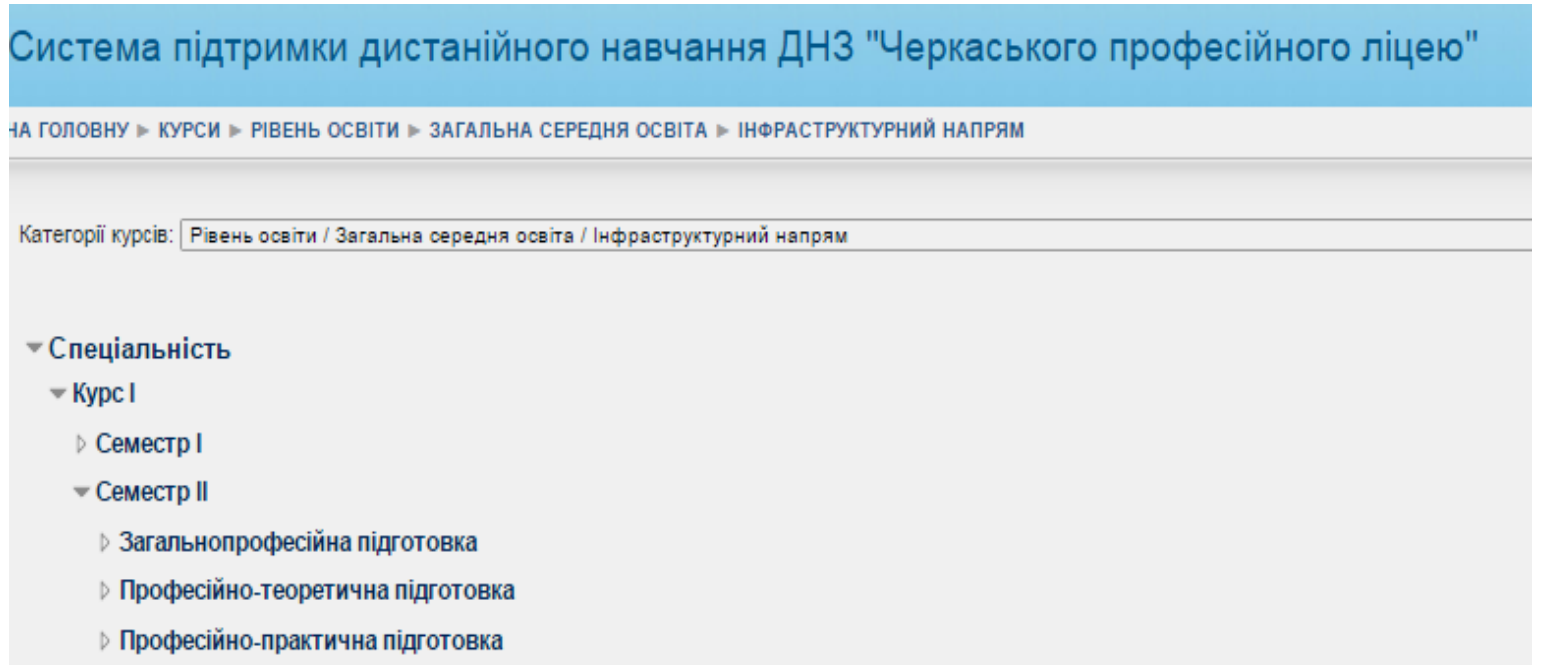

Рис. 8. Результат обрання підкатегорї̈ «Інфраструктурний напрям»

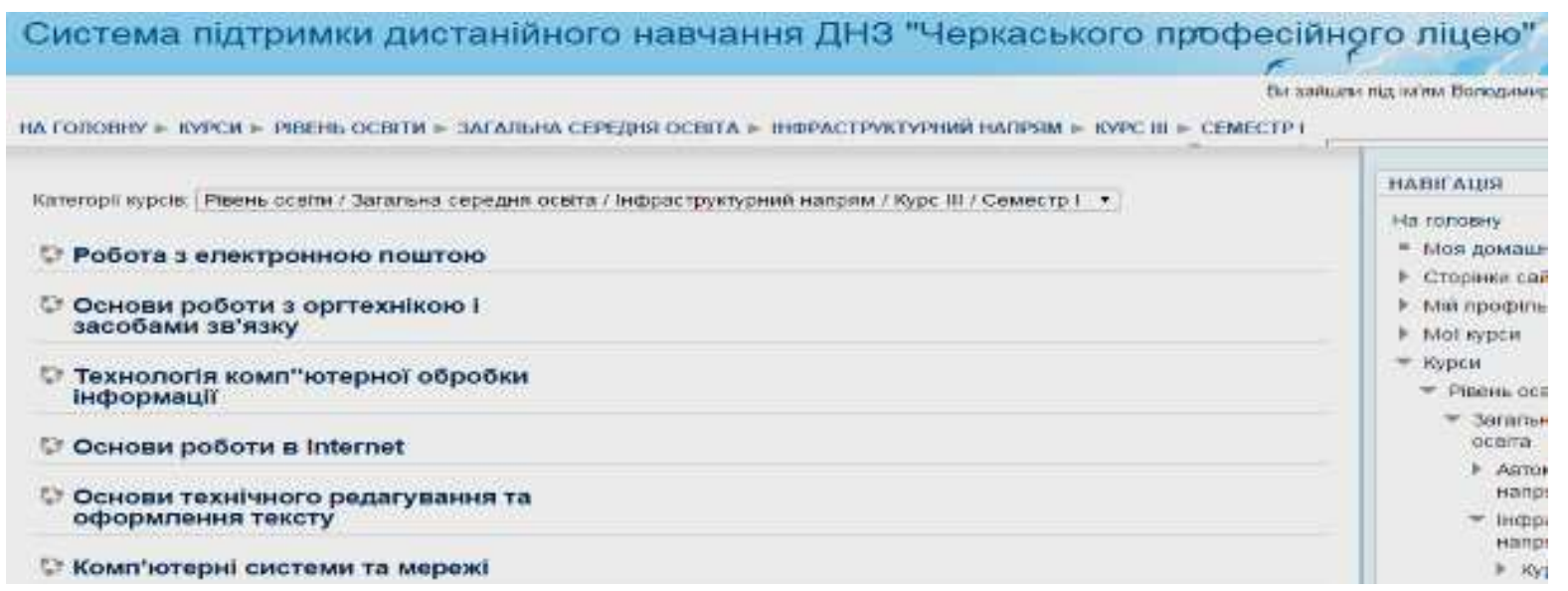

Рис. 9. Результат обрання підкатегорії «Семестр II»

Після обрання семестру користувач одержує відомості про види підготовки і навчальні предмети, що в них вивчаються.

Однією зі складових дидактичного забезпечення навчального процесу учнів ПТНЗ $\epsilon$ електронні навчальні курси (ЕНК) з окремих дисциплін або циклів дисциплін, що розміщуються в СПДН.

\section{2. Структура електронного навчального курсу в СПДН ПТНЗ}

Електронний навчальний курс - електронний освітній ресурс, що є комплексом навчально-методичних матеріалів, представлених в електронній формі, достатніх для організації індивідуального і групового навчання окремої навчальної дисципліни у спеціалізованому середовищі, що функціонує на базі сучасних психолого-педагогічних та інформаційно-комунікаційних технологій [3].

У системі розміщено типовий шаблон електронного навчального курсу, що використовується адміністратором СПДН для розгортання курсів дистанційного навчання в ПТНЗ. 
Кожен ЕНК має визначену структуру, до шаблону якого входять такі блоки:

- загальні відомості про курс;

- вхідний контроль з курсу;

- теоретичний навчальний матеріал;

- матеріали для практичної підготовки;

- самостійна робота учнів і контроль відвідування занять;

- поточний і тематичний контроль;

- підсумковий контроль.

На рис. 10-11 зображено фрагменти ЕНК «Комп'ютерні системи та мережі» (КСМ) в СПДН ПТНЗ «ЧПЛ».

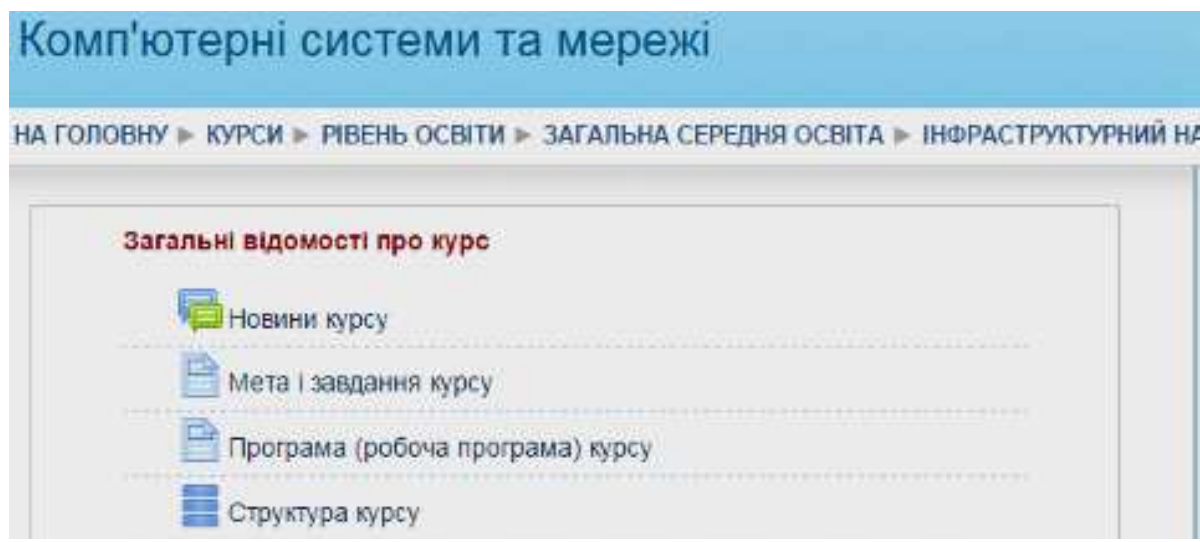

Рис. 10. Фрагмент електронного навчального курсу КСМ. Загальні відомості про курс

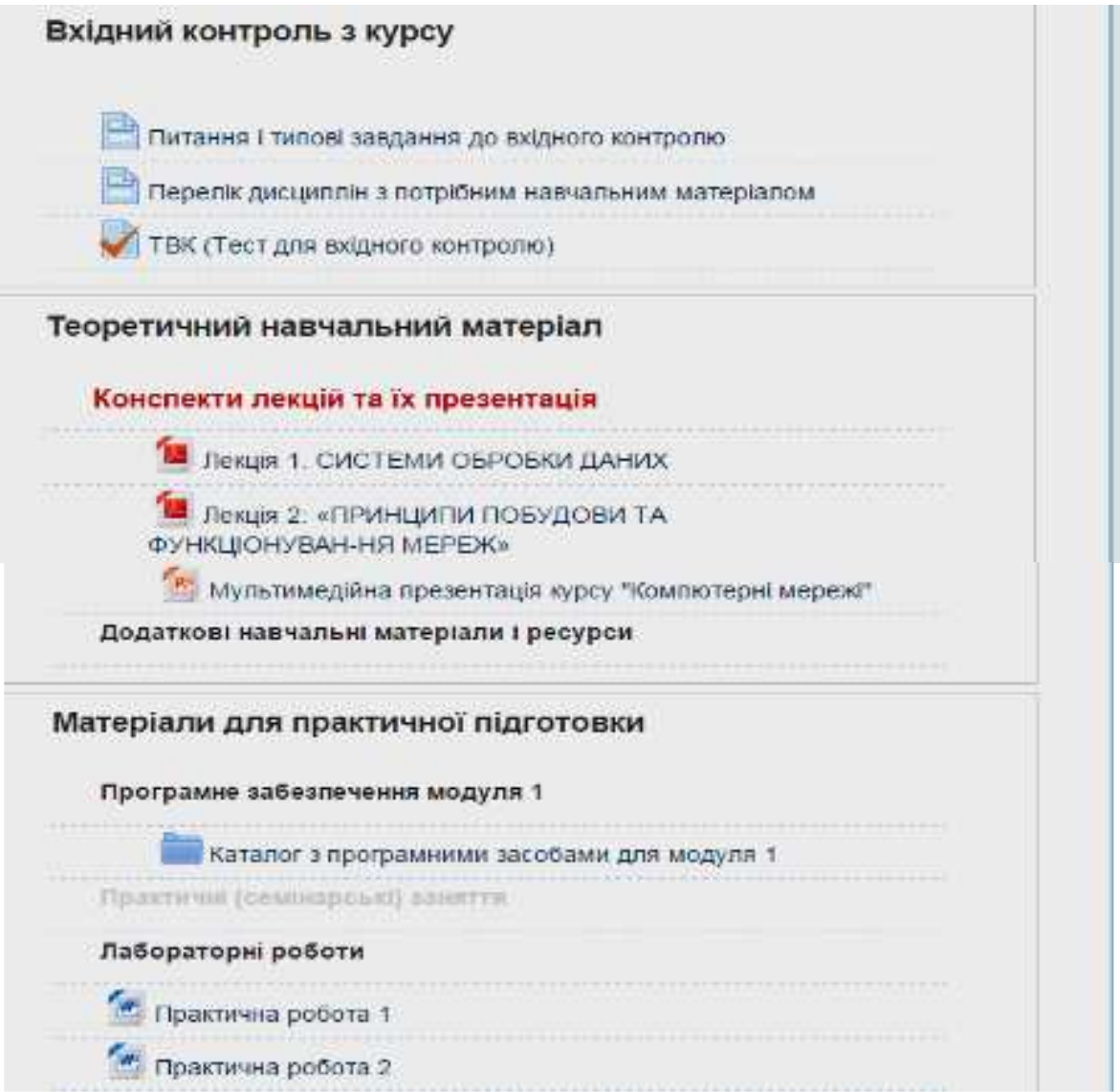

Рис. 11. Фрагмент електронного навчального курсу КСМ (продовження) 
Система підтримки дистанційного навчання ДНЗ «ЧПЛ» індексується офіційним сайтом Moodle [11] (рис. 12).

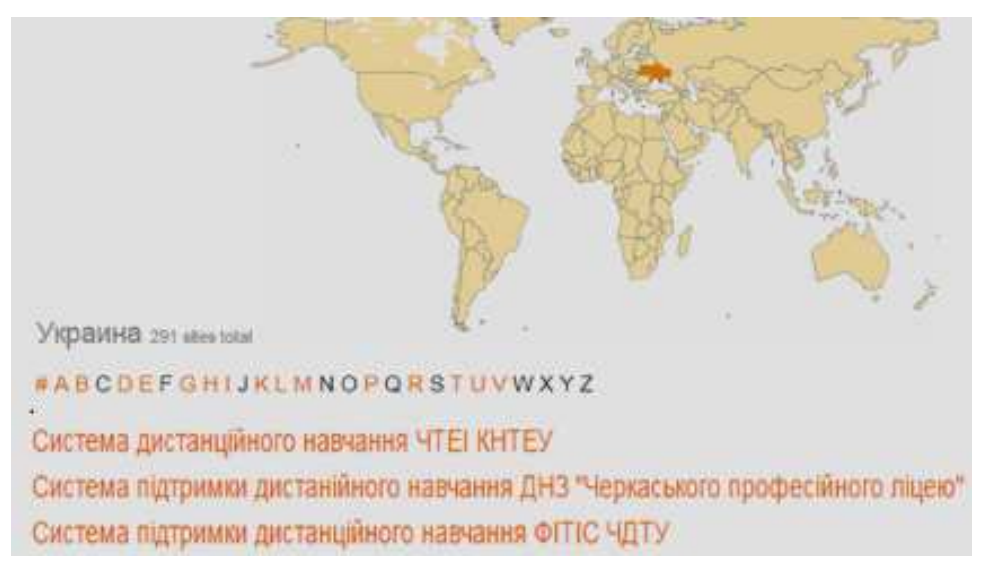

Puc. 12. Oфіиійинй caŭm Moodle [11]

\section{3. Інтегрування хмарних сервісів з СПДН ПТНЗ на базі Moodle}

Для розгортання даних блоків широко використовуються хмарні сервіси, які надають відповідні можливості для збереження і розробки навчальних матеріалів.

Сервіси «Google Apps for Education» [1] і «Microsoft Office 365 for Education» [2] включають широкий набір інструментів, які можна налаштувати під потреби користувача і навіть прив' язати, деякою мірою, до СПДН і бренду навчального закладу. Наразі описувані системи розміщуються на серверах зовнішнього постачальника послуг, у так званій «хмарі». Одним 3 аргументів на користь інтеграції СПДН 3 хмарними сервісами (Google «Apps for Education» або «Microsoft Office 365 for Education») $\epsilon$ використання ресурсів хмарних провайдерів, адже вони дешевші, ніж використання зазначених сервісів самим ПТНЗ. По суті, витрати взагалі відсутні. Користуючись хмарними сервісами ПТНЗ, немає необхідності планувати на майбутнє рівень навантаження на сервер для покриття короткочасних або довгострокових періодів зростання або спадання ділової активності. На рис. 13 зображено фрагмент вікна з можливими плагінами для СПДН на базі Moodle, що підтримують інтеграцію 3 відповідними хмарними сервісами.

Google запровадила засіб інтеграції між Google Apps i Moodle, що надає можливість використовувати єдиний вхід в обох системах. Таке рішення було розроблено компанією Moodle Rooms, яка вже реалізує розміщення системи Moodle в хмарі для освітніх установ 3 метою уникнення витрат на розміщення системи на серверах навчальних закладів.

\begin{tabular}{|c|c|c|c|}
\hline \multicolumn{4}{|c|}{ Penosиторіi } \\
\hline & Dropbox & Standard & 2013110500 \\
\hline & $\begin{array}{l}\text { Google Orive } \\
\text { repostory_goopledocs }\end{array}$ & Standard & 2013110500 \\
\hline & Amazon $\$ 33$ & Standard & 2013110500 \\
\hline & $\begin{array}{l}\text { Microsoft Skydrive } \\
\text { moposton, shyolive }\end{array}$ & Standard & 2013110500 \\
\hline & $\begin{array}{l}\text { Biximegia } \\
\text { reposocry_usimeda }\end{array}$ & Standard & 2013110500 \\
\hline & Youtube videos & Standard & 2013110500 \\
\hline
\end{tabular}

Pис. 13. Фрагмент вікна з плагінами в системі Moodle 


\section{3. ВИСНОВКИ ТА ПЕРСПЕКТИВИ ПОДАЛЬШИХ ДОСЛІДЖЕНЬ}

1. Тенденції до зростання ролі самостійної роботи учнів, поєднання різних форм організації навчання за рахунок широкого використання засобів IКТ, стимулюють упровадження в ПТНЗ СПДН 3 метою організацій цілеспрямованого процесу здобування знань, умінь та навичок в умовах інтеграції аудиторної і позааудиторної навчальної діяльності на основі взаємного доповнення технологій традиційного, дистанційного і мобільного навчання.

2. Організація навчального процесу за допомогою засобів СПДН ПТНЗ надає більшої свободи для діяльності як учнів, так і викладачів та їхніх батьків: значно розширюється освітній простір для здобування знань і самостійної роботи учнів, викладачі мають можливість застосовувати сучасні підходи і методи навчання, а батьки - брати безпосередню участь у процесі навчання і виховання своїх дітей за рахунок збільшення наочності, доступності навчальних матеріалів, автоматизації контролю та оцінювання результатів навчальної діяльності учнів, переходу до моделі змішаного навчання з широким використанням IКT.

3. Результати дослідження можуть бути використані для розгортання системи підтримки дистанційного навчання ПТНЗ; для впровадження змішаного навчання у ПТНЗ України; для створення електронних навчальних курсів у системі Moodle.

\section{СПИСОК ВИКОРИСТАНИХ ДЖЕРЕЛ}

1. Наказ Міністерства освіти і науки України «Про затвердження Положення про дистанційне навчання» № 466 від 25.04.2013 p. [Електронний ресурс]. - Режим доступу : http://zakon4.rada.gov.ua/laws/show/z0703-13.

2. Концепція проекту «Дистанційне навчання школярів» [Електронний ресурс] / [Ю. М. Богачков, В. Ю.Биков, В. О. Красношапка та ін.] // Інформаційні технології і засоби навчання. - 2009. - № 5 (13). - $\quad$ Режим доступу до журналу

http://journal.iitta.gov.ua/index.php/itlt/article/view/186/172\#.VcsXJ_ntmko.

3. Інформаційно-аналітична система контролю та оцінювання навчальної діяльності студентів ВНЗ : монографія / [А. А. Тимченко, Ю.В.Триус, І. В. Стеценко, Л. П. Оксамитна, В. М. Франчук, Г. О. Заспа, Д. П. Тупицький, О. В. Тьорло, І. В. Герасименко]. - Черкаси: МакЛаут, 2010. - 300 с.

4. Герасименко I. В. Використання технологій дистанційного навчання в підготовці майбутніх бакалаврів комп'ютерних наук [Електронний ресурс] / Герасименко Інна. Володимирівна // Інформаційні технології i засоби навчання. - 2014. - №3(41). - Режим доступу : http://journal.iitta.gov.ua/index.php/itlt/article/view/1080\#.U70eW_1_s-Q_ (дата актуальності 26.06.2014).

5. Богачков Ю. М. Ключові питання створення концепції мережі ресурсних центрів дистанційної освіти загальноосвітніх навчальних закладів / Ю.М.Богачков, О.П. Пінчук // Інформаційні технології і засоби навчання. - 2013. - Т. 35, вип. 3. - С. 83-98.

6. Биков В. Ю. Моніторинг рівня навчальних досягнень 3 використанням Інтернет-технологій : [монографія] / АПН України; Інститут інформаційних технологій і засобів навчання / Биков В. Ю., Богачков Ю. М., Жук Ю. О. - К. : Педагогічна думка, 2008. - 127 с.

7. Пінчук О. П. Організація та функціонування мережі ресурсних центрів дистанційної освіти загальноосвітніх нвчльних закладів: [монографія] / [Пінчук О. П., Богачков Ю. М., Биков В. Ю., Манако А. Ф., Олійник В. В., Буров О. Ю., Коневщинська О. Е., Іванюк І. В., Рождественська Д. Б., Барладим В.М., Корнієць О. М. Мушка I. В.]. - Київ , "Атіка" ISBN 978-966-326-477-6, 2014. $184 \mathrm{c}$.

8. Величко Н. О. Індикатори ефективної діяльності професійно-технічних навчальних закладів як інструментарій моніторингу якості і доступності освітніх послуг : [метод. реком.] / [Н. О. Величко, Л. А. Майборода, І. М. Савченко та ін.] ; за заг. ред. І. М. Савченко. - К. : Прінт, ВІАЦ, 2009. - 37 с. [Електронний ресурс]. - Режим доступу : http://ipto.kiev.ua/ index.php?option=com_content \&task=blogcategory\&id=54\&Itemid=56.

9. Майборода Л. А. Організаційно-правові засади створення інформаційно-аналітичних центрів ПТО : [метод. реком.] / Л. А. Майборода, І. М. Савченко. - К. : Принт, 2009. - 49 с. - [Електронний 
pecypc].

Режим

доступу:

http://ipto.kiev.ua/index.php?option=com_content\&task=blogcategory\&id=54\&Itemid =56.

10. Биков В. Ю. Технологія створення дистанційного курсу ^[навч. посібник] / [В. Ю. Биков, В. М. Кухаренко, Н. Г. Сиротенко, О.В. Рибалко, Ю. М. Богачков]; за ред. В. Ю. Бикова та В. М. Кухаренка. - К. : Міленіум, 2008. - 324 с.

11. Сайт системи Moodle [Електронний ресурс]. - Режим доступу : https://moodle.org.

12. Сайт системи Edmodo [Електронний ресурс]. - Режим доступу : https://www.edmodo.com.

13. Сайт системи Skillsoft [Електронний ресурc]. - Режим доступу : www.skillsoft.com.

14. Сайт системи Schoology [Електронний ресурc]. - Режим доступу : https://www.schoology.com.

15. Сайт системи Instructure [Електронний ресурс]. - Режим доступу : https://www.instructure.com.

16. The top 20 LMS Software [Electronic resource]. - Режим доступу : http://www.capterra.com/learningmanagement-system-software /\#infographic (дата актуальності 30.7.2015 p.).

17. Система підтримки дистанційного навчання Державного навчального закладу «Черкаський професійний ліцей» [Електронний ресурс]. - Режим доступу : http://profli.cdtu.edu.ua.

Матеріал надійшов до редакиї 29.04.2015 p.

\title{
ПРОЕКТИРОВАНИЕ СИСТЕМЫ ПОДДЕРЖКИ ДИСТАНЦИОННОГО ОБУЧЕНИЯ ПТУ
}

\author{
Глущенко Владимир Владимирович \\ аспирант \\ Институт информационных технологий и средств обучения НАПН Украины, г. Киев, Украина \\ reveikf@mail.ru
}

\begin{abstract}
Аннотация. В статье рассматривается система поддержки дистанционного обучения профессионально-технических учебных заведений на базе системы Moodle. Рассматриваются особенности проектирования и использования системы поддержки дистанционного обучения в профессионально-технических учебных заведениях; проектирование структуры системы поддержки дистанционного обучения профессионально-технических учебных заведений; основные этапы внедрения системы поддержки дистанционного обучения в образовательный процесс профессиональнотехнических учебных заведений на базе Moodle. Разрабатывается прототип системы поддержки дистанционного обучения профессионально-технических учебных заведений и на его основе разворачивается система поддержки дистанционного обучения Государственного учебного заведения «Черкасский профессиональный лицей».
\end{abstract}

Ключевые слова: информационно-коммуникационные технологии; дистанционное обучение; система поддержки дистанционного обучения; электронный учебный курс; Moodle.

\section{DESIGNING SUPPORT SYSTEM OF DISTANCE LEARNING IN VOCATIONAL EDUCATIONAL INSTITUTIONS}

\author{
Volodymyr V. Hlushchenko \\ postgraduate \\ Institute of Information Technologies and Learning Tools of NAES of Ukraine, Kiev, Ukraine \\ reveikf@mail.ru
}

\begin{abstract}
In the article the system of distance learning in vocational education system based on Moodle is considered. The features of the system design and the use of e-learning in vocational schools; designing the system structure for distance learning in vocational education; main stages of implementation of distance learning in the educational process of vocational education based on Moodle are considered. There has been developed the prototype support system for distance learning in State educational establishment "Cherkasky professional college."
\end{abstract}


Keywords: information and communication technologies; distance learning; system of distance learning; e-learning courses; Moodle.

\section{REFFERENCES (YRANSLATED AND TRANSLITERATED)}

1. Ministry of Education and Science of Ukraine «On Approval of distance education» № 466 from 25.04.2013 p. [online]. - Available from: http://zakon4.rada.gov.ua/laws/show/z0703- 13 (in Ukrainian)..

2. The concept of the «Distance Learning students» [online] / Y. M Bohachkov, V. Yu. Bykov, V .O. Krasnoshapka and others. // Information technology and learning tools. - 2009. - № 5 (13). - Available from: http://www.ime.edu-ua.net/em.html. - Name of the dividers. screen.(in Ukrainian).

3. Information-analytical system of monitoring and evaluation of educational activities of university students: Monograph / A. A. Timchenko, Y. V. Trius, I. V Stecenko, L. P Oksamytna, V. M. Franchuk, G. A. Zaspa, D. P. Tupytskyy, A. V. Torlo, I. V. Gerasimenko. - Cherkasy: MakLaut, 2010. - 300 p. (in Ukrainian).

4. Gerasimenko I. V. Use of distance learning technologies in training future bachelors in computer science [online] / Gerasimenko I. V. // Information technology and learning tools. - 2014. - №3 (41). - Available from: http://journal.iitta.gov.ua/index.php/itlt/article/view/1080\#.U70eW_1_s-Q (date 26/06/2014) (in Ukrainian).

5. Bohachkov M. Key issues creating the concept of a network resource centers of distance education of secondary schools / Bohachkov M., Pinchuk A. P. // Information technologies and means of teaching. 2013. - Vol 35, no. 3. - P. 83-98. (in Ukrainian).

6. Bykov V.U. Monitoring the level of educational achievement using Internet technologies [monograph] / Pedagogical Sciences of Ukraine; Institute of Information technology and training / Bykov V. Y., Bohachkov Y. M., Zyku Y. O. - K., Educational thought, 2008. - 127 p. (in Ukrainian).

7. Velichko N. O. Indicators of effective vocational education as tools monitor the quality and accessibility of educational services: [method. recom.] [online] / N. O Velichko, L. A. Majboroda, I. N. Savchenko and others. ; by the Society. ed. I. M. Savchenko. - K. : Print, VIAC, 2009. - 37 p. - - Available from: http://ipto.kiev.ua/ index.php? Option $=$ com_content $\&$ task $=$ blogcategory $\&$ id $=54 \&$ Itemid $=56$ (in Ukrainian).

8. Pinchuk, A. P. The organization and functioning of a network of resource centers of distance education of secondary schools nvchlnyh: [monograph] / Pinchuk A. P., Bohachkov Y. M., V. Y. Bykov, Manakov, A. F., Oliynyk V. V., Burov A. Y.., Konevschynska O. E., Ivanyuk I. V., Christmas D. B., Barladym V. M. Korniets A. M., Mushka I. V. - . Kyiv : "Atika" ISBN 978-966-326-477-6, 2014. - 184 s. (in Ukrainian).

9. Majboroda L. A. Organizational and Legal Basis creation of information and analytical centers: [method. Recom.] [online] / L. A. Majboroda, I. N. Savchenko. - K. : Print, 2009. - 49 p. - Available from: http://ipto.kiev.ua/index.php?option=com_content\&task=blogcategory\&id $=54 \&$ Itemid=56 (in Ukrainian).

10. Bykov V. Y. Technology of distance course [teach. user] / V. Y. Bykov, V. M. Kukharenko, N. G. Syrotenko, O. V. Rybalko, Y. M. Bohachkov ; eds. V. Y. Bykov and V. M. Kukharenko - K .: Millenium, 2008. - 324 p. (in Ukrainian).

11. Moodle [online]. - Available from: https://moodle.org. (in Russian).

12. Edmodo [online]. - Available from: https://www.edmodo.com. (in English).

13. Skillsoft [online]. - Available from: www.skillsoft.com. (in English).

14. Schoology [online]. - Available from: https://www.schoology.com. (in English).

15. .Instructure [online]. - Available from: https://www.instructure.com. (in English).

16. The top 20 LMS Software [online]. - Available from: http://www.capterra.com/learning-managementsystem-software /\#infographic. (in English).

17. System of distance learning State educational institution «Cherkasky professional college». [online]. Available from: http://profli.cdtu.edu.ua (in Ukrainian).

\section{$(\mathrm{Cc}) \mathrm{EY}$-NC-SA}

This work is licensed under Creative Commons Attribution-NonCommercial-ShareAlike 4.0 International License. 